\title{
Immunosuppressive effect of hispidulin in allergic contact dermatitis
}

\author{
Premrutai Thitilertdecha ${ }^{1}$, Panwadee Pluangnooch ${ }^{2}$, Sunita Timalsena ${ }^{2}$ and Kitipong Soontrapa ${ }^{2^{*}}$
}

\begin{abstract}
Background: Long-term use of most immunosuppressants to treat allergic contact dermatitis (ACD) generates unavoidable severe side effects, warranting discovery or development of new immunosuppressants with good efficacy and low toxicity is urgently needed to treat this condition. Hispidulin, a flavonoid compound that can be delivered topically due to its favorable skin penetrability properties, has recently been reported to possess antiinflammatory and immunosuppressive properties. However, no studies have investigated the effect of hispidulin on Th1 cell activities in an ACD setting.

Methods: A contact hypersensitivity (CHS) mouse model was designed to simulate human ACD. The immunosuppressive effect of hispidulin was investigated via ear thickness, histologic changes (i.e., edema and spongiosis), and interferon-gamma (IFN- $\gamma$ ) gene expression in 1-fluoro-2,4-dinitrobenzene (DNFB)-sensitized mice. Cytotoxicity, total number of $C D 4^{+} \mathrm{T}$ cells, and percentage of IFN- - -producing $C D 4^{+} \mathrm{T}$ cells were also investigated in vitro using isolated $C D 4^{+} T$ cells from murine spleens.

Results: Topically applied hispidulin effectively inhibited ear swelling (as measured by reduction in ear thickness), and reduced spongiosis, IFN- $\gamma$ gene expression, and the number of infiltrated immune cells. The inhibitory effect of hispidulin was observed within $6 \mathrm{~h}$ after the challenge, and the observed effects were similar to those effectuated after dexamethasone administration. Hispidulin at a concentration up to $50 \mu \mathrm{M}$ also suppressed IFN- $\gamma$-producing $\mathrm{CD}^{+} \mathrm{T}$ cells in a dose-dependent manner without inducing cell death, and without a change in total frequencies of $\mathrm{CD}^{+} \mathrm{T}$ cells among different concentration groups.
\end{abstract}

Conclusion: The results of this study, therefore, suggest hispidulin as a novel compound for the treatment of ACD via the suppression of IFN- $\gamma$ production in Th1 cells.

Keywords: Hispidulin, Immunosuppressive drug, Contact hypersensitivity, Atopic dermatitis, T cells, 1-fluoro-2,4dinitrobenzene

\section{Background}

Allergic contact dermatitis (ACD), also known as contact hypersensitivity (CHS), is a type $1 \mathrm{~T}$ helper (Th1) cell-mediated inflammatory skin disease caused by repeated topical exposure to a previously sensitized. A CHS mouse model has been utilized in studies on the pathophysiology of ACD [1-3]. For treatment of ACD, topical and systemic administrations of immunosuppressive drugs, such as corticosteroids, cyclosporine-A and tacrolimus, are normally used. However, these drugs associated with various adverse effects after prolonged use

\footnotetext{
* Correspondence: kitipong.soo@mahidol.ac.th

${ }^{2}$ Department of Pharmacology, Faculty of Medicine Siriraj Hospital, Mahidol

University, 2 Wanglang Road, Bangkoknoi, Bangkok 10700, Thailand
}

Full list of author information is available at the end of the article
[4-6], so it is of importance to find a novel candidate compound to treat ACD. Recently, phytochemicals have become good candidate active compounds for drug discovery and for the development of novel immunosuppressive treatments for ACD due to their high efficacy and low toxicity.

Hispidulin (4',5,7-trihydroxy-6-methoxyflavone), a flavonoid compound found in several plants [7-13], has recently been investigated for its anti-inflammatory and immunosuppressive ability to treat several inflammatory and autoimmune diseases. Previously, a number of reports showed that hispidulin suppressed inflammations in mouse models of 12-O-tetradecanoylphorbol-13-acetate (TPA)-induced ear edema $[9,10]$, croton oil-induced

(c) The Author(s). 2019 Open Access This article is distributed under the terms of the Creative Commons Attribution 4.0 International License (http://creativecommons.org/licenses/by/4.0/), which permits unrestricted use, distribution, and reproduction in any medium, provided you give appropriate credit to the original author(s) and the source, provide a link to the Creative Commons license, and indicate if changes were made. The Creative Commons Public Domain Dedication waiver (http://creativecommons.org/publicdomain/zero/1.0/) applies to the data made available in this article, unless otherwise stated. 
dermatitis [12], ultraviolet A radiation-induced skin damage [14], and passive cutaneous anaphylaxis [15]. At the cellular level, hispidulin could inhibit functions of various immune cells like $\mathrm{T}$ cells [13], macrophages [10] and mast cells [15]. Its anti-inflammatory activity was reported to be mediated via nuclear factor erythroid 2related factor 2 (Nrf2)/heme oxygenase ( $\mathrm{HO})$-1 signaling [10], not nuclear factor kappa-light-chain-enhancer of activated B cells (NF- $\mathrm{kB}$ ) induction [11], and downregulation of inducible nitric oxide synthase (iNOS) and cyclooxygenase (COX)-2 expressions [8]. Although many anti-inflammatory and immunosuppressive properties of hispidulin have been appreciated, the effect of hispidulin on ACD via Th1 cell activities has not been explored yet. Accordingly, the aim of this study was to investigate the immunosuppressive effect of purified hispidulin on Th1 cell function in the DNFB-induced CHS mouse model.

\section{Materials and methods Animals}

Male C57BL/6 mice, 7-10 weeks of age, were obtained from the National Laboratory Animal Center, Mahidol University, Salaya Campus, Nakhon Pathom, Thailand. All mice were housed in a 12-h/12-h light/dark specific pathogen-free condition, with free access to standard rodent feed and water. The care and treatment of study mice was in accordance with the guidelines of Mahidol University and the Office of the National Research Council of Thailand (NRCT). The total number of animals used in each experimental group was referred from the published article conducting the similar experiments [16]. All experimental protocols were approved by the Siriraj Animal Care and Use Committee (Si-ACUC), Faculty of Medicine Siriraj Hospital, Mahidol University, Bangkok, Thailand (COA no. 015/2559).

\section{Chemicals and reagents}

Fluorescein isothiocyanate (FITC) conjugated antibody to mouse $\mathrm{CD} 4$, and purified antibodies to mouse-CD3, $-\mathrm{IL}-4$, and -CD28 were purchased from eBioscience, Inc. (San Diego, CA, USA). Phycoerythrin (PE) conjugated antibody to mouse-IFN- $\gamma$, and recombinant mouse (rm) IL-12 were purchased from BioLegend, Inc. (San Diego, CA, USA). Recombinant mouse IL-2 was purchased from ImmunoTools $\mathrm{GmbH}$ (Friesoythe, Germany). 1-Fluoro-2,4-dinitrobenzene (DNFB), hispidulin (purity >98\%), dexamethasone, phorbol 12myristate 13-acetate (PMA), and ionomycin were purchased from Sigma-Aldrich Corporation (St. Louis, MO, USA). Paraformaldehyde was purchased from Merck (Darmstadt, Germany). GolgiPlug ${ }^{\text {Tx }}$ Protein Transport Inhibitor and Cytofix/Cytoperm ${ }^{\text {TM }}$ Fixation/ Permeabilization Solution Kit were purchased from BD
Biosciences (Franklin Lakes, NJ, USA). Propidium iodide (PI) solution was purchased from Miltenyi Biotec (Bergisch Gladbach, Germany). Phosphate buffered saline (PBS) was purchased from AMERESCO, Inc. (Framingham, MA, USA. Roswell Park Memorial Institute (RPMI)-1640 Complete Medium (Gibco; Thermo Fisher Scientific, Waltham, MA, USA), fetal bovine serum (FBS) (Biochrom; Merck, Darmstadt, Germany), olive oil (ChemCruz ${ }^{\mathrm{mw}}$; Santa Cruz Biotechnology, Inc., Dallas, TX, USA), acetone (Scharlau; Scharlab, S.L., Barcelona, Spain), and thiopental sodium (THIOPEN; Unique Pharmaceutical Laboratories Ltd., Ankleshwar, India) were also used.

\section{Induction of contact hypersensitivity (CHS)}

Twenty-five mice were sensitized by painting $25 \mu \mathrm{L}$ of $0.5 \%$ DNFB in a mixture solution of acetone and olive oil $(4: 1, v / v)$ on the shaved abdomen (day 0$)$ with the average area of $2 \times 2 \mathrm{~cm}$. Five days after sensitization, mice were elicited by painting $20 \mu \mathrm{L}$ of $0.3 \%$ DNFB in the same vehicle on the dorsal and ventral pinna of both ears. For the topical application of drug compounds, mouse pinna was applied with either hispidulin $(10$ or $30 \mu \mathrm{g} /$ ear, treatment groups, $n=5$ each concentration), dexamethasone $(30 \mu \mathrm{g} / \mathrm{ear}$, positive control, $n=5$ ), or no treatment (the vehicle alone, a sensitized control, $n=5$ ) starting on day 4 for 3 consecutive days. Mice sensitized and elicited with vehicle alone were used as a non-sensitized control $(n=5)$. Ear thickness of each ear of each individual mouse was measured at pre-challenge and at 6-, 24-, and $48-\mathrm{h}$ post-challenge using a Vernier caliper (Mitutoyo, Kanagawa, Japan).

\section{Histopathologic examination}

At 48-h post-challenge, all mice were sacrificed by intraperitoneal injection of thiopental sodium $(50 \mathrm{mg} / \mathrm{kg})$. The mouse pinna was resected, fixed with $4 \%$ paraformaldehyde, and embedded in paraffin. Sections $(5 \mu \mathrm{m}$ thick) were stained with hematoxylin and eosin (H \& E) for histopathologic evaluation of CHS.

\section{Measurement of IFN- $\gamma$ gene expression}

Total ribonucleic acid (RNA) was isolated from the excised pinna from one ear per mice at 24-h postchallenge using a Total RNA Extraction Kit (RBC Bioscience, New Taipei City, Taiwan). Complementary deoxyribonucleic acid (cDNA) was then synthesized from $1 \mu \mathrm{g}$ of total RNA using an iScript ${ }^{\mathrm{m}}$ Select cDNA Synthesis Kit (Bio-Rad Laboratories, Inc., Hercules, CA, USA). Real-time polymerase chain reaction (real-time PCR) analysis was performed using a LightCycler ${ }^{\circ} 480$ Instru- $^{-}$ ment II (Roche Applied Science, Penzberg, Germany). The final reaction mixture in each reaction tube 
consisted of $0.5 \mu \mathrm{L}$ of cDNA; $0.4 \mu \mathrm{L}$ of sense and antisense primer solutions, including IFN- $\gamma$ (forward: $5^{\prime}$ AACGCTACACACTGCATCT-3', reverse: $5^{\prime}$-TGCTCA TTGTAATGCTTGG-3') and $\beta$-actin (ACTB, forward: 5'-ATGGATGACGATATCGCT-3', reverse: 5' - ATG AGGTAGTCTGTCAGGT-3') (Integrated DNA Technologies, Coralville, IA, USA); $10 \mu \mathrm{L}$ of KAPA SYBR ${ }^{\circ}$ Fast qPCR Master Mix (2x) Kit (Kapa Biosystems, Wilmington, MA, USA); and, $8.7 \mu \mathrm{L}$ of sterile Milli- ${ }^{\circ}$ water (Merck). The conditions for reverse transcription and the PCR steps were according to the manufacturer's instructions. The normalization and quantification of mRNA expression was performed using LightCycler ${ }^{\circ} 480$ software (Roche Applied Science, Rotkreuz, Switzerland).

\section{In vitro testing for drug toxicity}

Three naïve mice were sacrificed by intraperitoneal injection of thiopental sodium $(50 \mathrm{mg} / \mathrm{kg})$. Naïve $\mathrm{CD} 4^{+} \mathrm{T}$ cells were isolated from spleens by using CD4 MicroBeads and a MiniMACS ${ }^{\text {TM }}$ Separator (Miltenyi Biotec) according to the manufacturer's instructions. The isolated $\mathrm{CD} 4^{+} \mathrm{T}$ cells were then cultured at a cell density of $1 \times$ $10^{5}$ cells/well in RPMI 1640 Complete Medium containing $10 \%$ FBS. Cells were also incubated in the absence or presence of hispidulin at different concentrations of $6.25 \mu \mathrm{M}, 12.5 \mu \mathrm{M}, 25 \mu \mathrm{M}$, and $50 \mu \mathrm{M}$ for 7 days. After incubation, cells were stained with propidium iodide (PI) and analyzed using a CytoFLEX Flow Cytometer and CytExpert software (Beckman Coulter, Inc., Brea, California, US).

\section{Th1 cell differentiation assay and intracellular cytokine staining for IFN- $\gamma$ production}

Isolated naïve $\mathrm{CD} 4^{+} \mathrm{T}$ cells were obtained from spleens of four naive mice using CD4 MicroBeads and a MiniMACS $^{\text {tw }}$ Separator (Miltenyi Biotec), and then cultured in RPMI 1640 Complete Medium containing 10\% FBS. For Th1 cell differentiation, isolated $\mathrm{CD}_{4}{ }^{+} \mathrm{T}$ cells were stimulated with anti-CD3 $(10 \mu \mathrm{g} / \mathrm{mL})$ and anti-CD28 $(5 \mu \mathrm{g} / \mathrm{mL})$ for 2 consecutive days. Activated cells were then cultured in Th1-skewing condition consisting of recombinant mouse $(\mathrm{rm}) \mathrm{IL}-2(2500 \mathrm{U} / \mathrm{mL}), \mathrm{rm}$. IL-12 $(10 \mathrm{ng} / \mathrm{mL})$, and anti-IL-4 $(10 \mu \mathrm{g} / \mathrm{mL})$, together with/without hispidulin $(6.25 \mu \mathrm{M}, 12.5 \mu \mathrm{M}, 25 \mu \mathrm{M}$, and $50 \mu \mathrm{M})$ for 7 days prior to intracellular cytokine staining for IFN- $\gamma$ production.

For intracellular cytokine staining, cultured $\mathrm{CD}^{+} \mathrm{T}$ cells at $1 \times 10^{6}$ cells $/ \mathrm{mL}$ were stimulated with $50 \mathrm{ng} /$ $\mathrm{mL}$ PMA and $1 \mu \mathrm{g} / \mathrm{mL}$ ionomycin in the presence of GolgiPlug $^{\mathrm{Tm}}$ Protein Transport Inhibitor containing brefeldin A (BFA). Stimulated cells were then incubated at $37{ }^{\circ} \mathrm{C}$ in a $5 \% \mathrm{CO}_{2}$ condition for $4 \mathrm{~h}$ before being surface stained with anti-mouse CD4 FITC at $4{ }^{\circ} \mathrm{C}$ for $30 \mathrm{~min}$ and then washed once. Stained cells were then fixed and permeabilized with $0.1 \mathrm{~mL}$
Cytofix/Cytoperm ${ }^{\text {tw }}$ solution (BD Biosciences) at $4{ }^{\circ} \mathrm{C}$ for $20 \mathrm{~min}$ and washed with BD Perm/Wash ${ }^{\text {TM }}$ Buffer (BD Biosciences) prior to centrifugation at $500 \mathrm{~g}$ for 5 min. Intracellular cytokine staining (ICS) was performed using anti-IFN- $\gamma \mathrm{PE}$ at $4{ }^{\circ} \mathrm{C}$ for $30 \mathrm{~min}$ before washing with $\mathrm{BD}$ Perm/Wash ${ }^{\mathrm{Tu}}$ Buffer and resuspension in PBS. Stained samples were analyzed using a CytoFLEX Flow Cytometer and CytExpert software (Beckman Coulter).

\section{Statistical analysis}

All data were analyzed using GraphPad Prism 7 software (GraphPad Software, San Diego, CA, USA), and are presented as mean \pm standard deviation. One-way analysis of variance (ANOVA) followed by Bonferroni correction was used for multiple comparisons. Differences with a $p$ value less than 0.05 were considered statistically significant.

\section{Results \\ Hispidulin-induced suppression of CHS responses}

To evaluate the immunosuppressive effect of hispidulin on ACD, a CHS mouse model was designed using DNFB for sensitization and elicitation (Fig. 1a). Data presented in Fig. 1b show that DNFB-mediated mice developed marked ear swelling when compared to sham immunized mice. Treatment with hispidulin at both the 10 and $30 \mu \mathrm{g}$ concentrations was able to significantly reduce ear swelling within $6 \mathrm{~h}$ when compared to the sensitized control. The decrease in ear thickness after being treated with $30 \mu \mathrm{g} /$ ear hispidulin was comparable to the decrease in ear thickness observed after treatment with dexamethasone at 6- and 24-h post-challenge. The observed suppression was then substantially decreased at 48-h post-challenge when compared to dexamethasone; however, the $30 \mu \mathrm{g}$ hispidulin-treated ears still showed observably better suppression than the sensitized control.

\section{Hispidulin-induced attenuation of ear edema and spongiosis in CHS mice}

Histopathological changes in the excised ears revealed dermal thickness and infiltration of immune cells were both markedly increased in DNFB-sensitized mouse controls [Fig. 2, Additional file 1] when compared to the non-sensitized mice [DNFB (-)]. After hispidulin treatment of $30 \mu \mathrm{g} / \mathrm{ear}$, ear edema and spongiosis were reduced to almost the same levels as those observed after dexamethasone application [DNFB (+)/His30 vs. DNFB $(+) /$ Dex]. Remnants of infiltrated inflammatory cells was observed in the dermis in both the hispidulin and dexamethasone groups. 


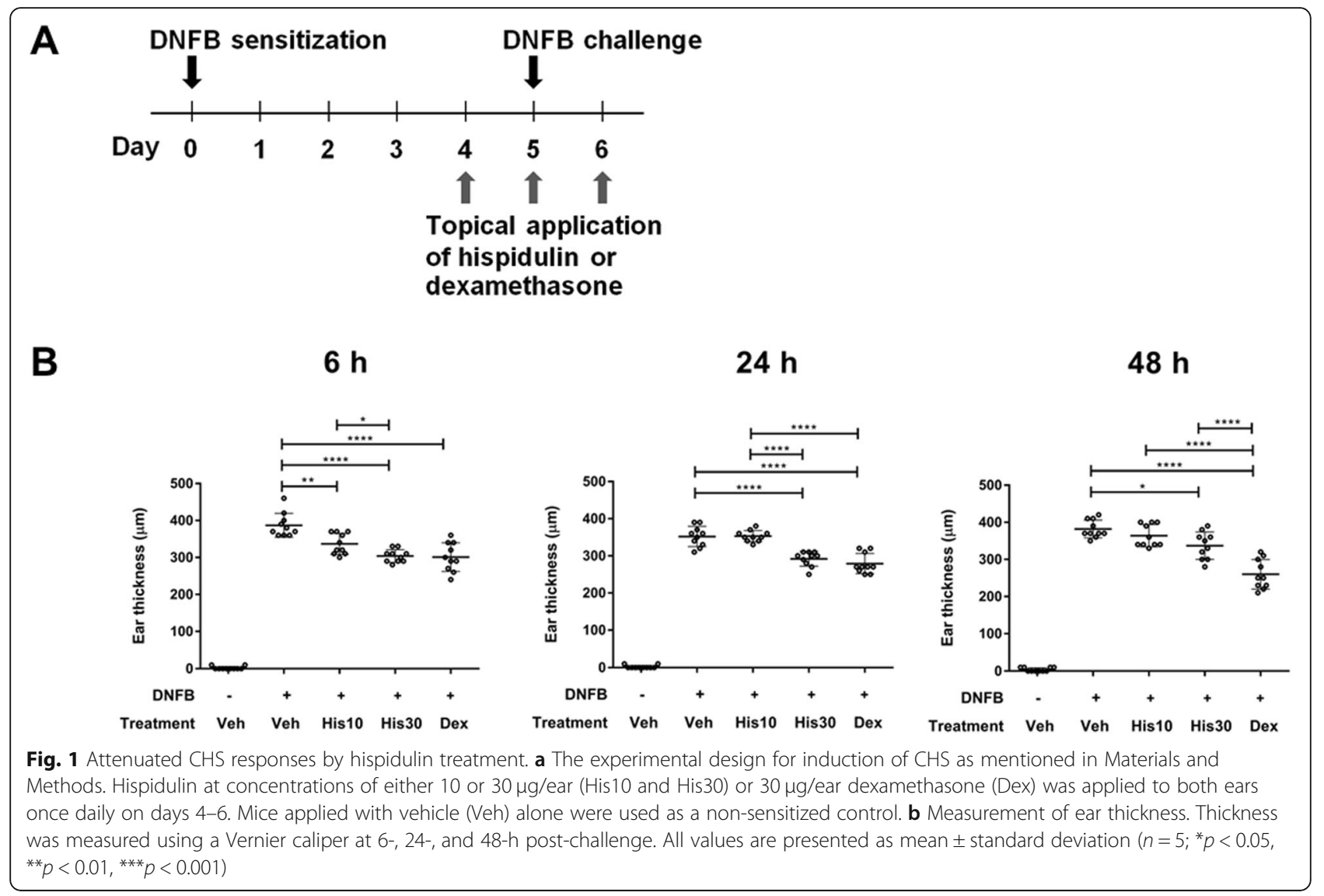

Downregulation of IFN- $\gamma$ gene expression in vivo after treatment with hispidulin

As Th1 cells secreting IFN- $\gamma$ play an important role, the mRNA expression of IFN- $\gamma$ in excised ear tissue was determined using real-time PCR. Relative mRNA expression of IFN- $\gamma$ to that of $\beta$-actin was considerably increased $(p=0.0002)$ after DNFB sensitization and challenge when compared to that of the non-sensitized group (Fig. 3). Hispidulin treatment of $30 \mu \mathrm{g} / \mathrm{ear}$ was able to significantly downregulate IFN- $\gamma$ expression $(p=$
0.0236), with results comparable to those observed after treatment with dexamethasone.

\section{Hispidulin-induced inhibition of T cell proliferation and Th1 cell differentiation in vitro}

For drug cytotoxicity, the tests revealed no change in the percentages of $\mathrm{CD}^{+} \mathrm{T}$ cell death compared to untreated controls (Fig. 4a). The total number of $\mathrm{CD} 4^{+} \mathrm{T}$ cells and the percentage of IFN- $\gamma$-producing $\mathrm{CD}^{+} \mathrm{T}$ cells cultured in the Th1-skewing condition were significantly

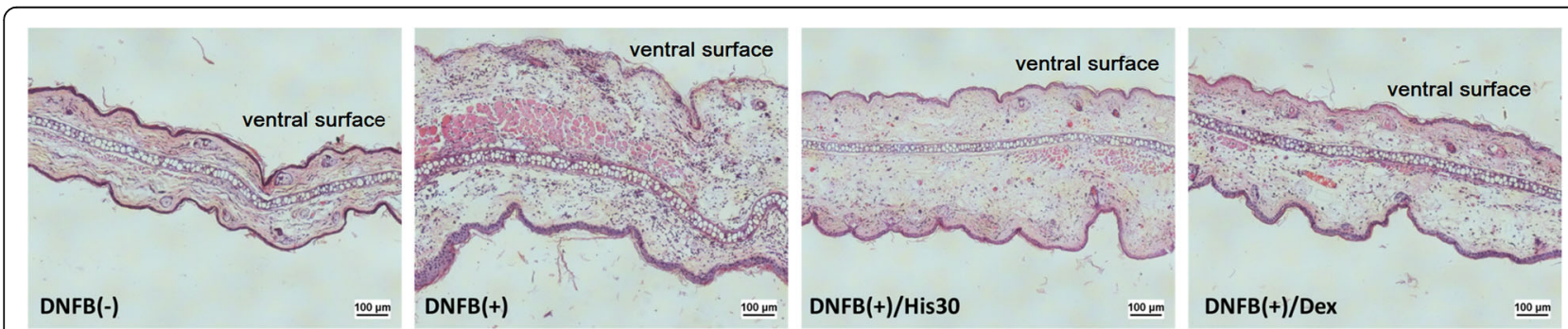

Fig. 2 Representative photomicrographs of DNFB-sensitized mouse pinna after hispidulin treatment. Transverse sections of murine ears with no sensitization [DNFB (-)], DNFB sensitization [DNFB (+)], and DNFB sensitization together with treatment of $30 \mu \mathrm{g} / \mathrm{ear}$ hispidulin (His30) or $30 \mu \mathrm{g} / \mathrm{ear}$ dexamethasone (Dex) were compared at 24-h post-challenge. All tissues were stained with hematoxylin and eosin $(\mathrm{H} \& \mathrm{E})$ 


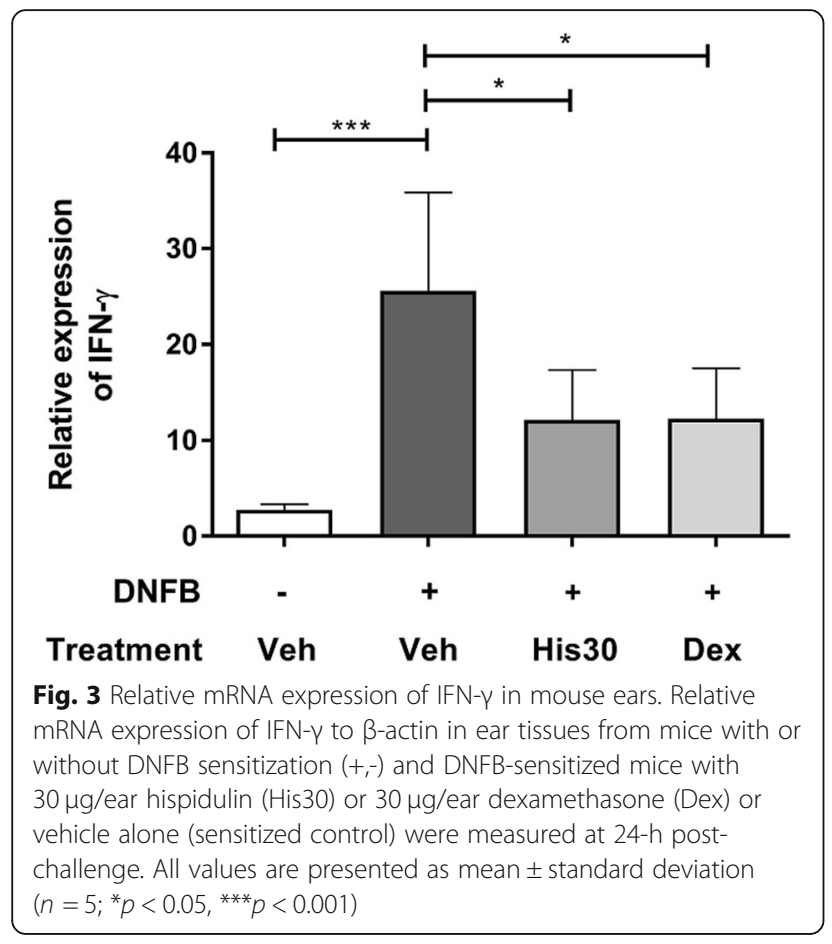

higher than the total number and percentage of cells cultured in complete medium (Fig. 4b and c; $p<0.0001$ and $p=0.0007$, respectively), which suggests that the Th1-skewing condition successfully induced Th1 cell differentiation. Hispidulin at all concentrations effectuated marked suppression of $\mathrm{CD} 4^{+} \mathrm{T}$ cell proliferation when compared to the suppression observed in the untreated control $(p<0.01)$, and no difference was observed among the 4 different hispidulin concentrations (Fig. 4b). However, hispidulin significantly reduced frequencies of IFN- $\gamma$-producing $\mathrm{CD}^{+}{ }^{+} \mathrm{T}$ cells in a dosedependent manner when compared to those observed in the untreated control (Fig. 4c; $p<0.01$ for 6.25 and $12.5 \mu \mathrm{M}, p=0.0010$ for $25 \mu \mathrm{M}$ and $p=0.0005$ for $50 \mu \mathrm{M})$. These findings suggest that hispidulin effectively inhibited $\mathrm{CD}_{4}^{+} \mathrm{T}$ cell function, most notably IFN- $\gamma$ production, without interrupting cell frequencies.

\section{Discussion}

In this study, we demonstrated the immunosuppressive effect of hispidulin on ACD using in vivo assay in CHS mouse model to simulate ACD reaction, and in in vitro study to demonstrate the effect of hispidulin on Th 1 cells. The animal models employed in this study showed that sensitization and elicitation with DNFB increased ear thickness, edema, and spongiosis, as well as increasing mRNA expression level of IFN- $\gamma$ in inflamed tissues. These responses suggest the suitability of our CHS protocol.

We found that hispidulin at 10 and $30 \mu \mathrm{g} /$ ear were able to reduce ear swelling within $6 \mathrm{~h}$ post-challenge, which confirms the previously reported findings that hispidulin inhibited 12-O-tetradecanoylphorbol-13-acetate (TPA)-induced murine ear edema $[9,10]$, and inhibited croton oil-induced dermatitis in mouse ears [12]. We also found a $30 \mu \mathrm{g} / \mathrm{ear}$ dose of hispidulin to have an inhibitory effect comparable to that of a $30 \mu \mathrm{g} /$ ear dose of dexamethasone, which is similar to a dose causing $50 \%$ inhibition of inflammatory responses in vivo $\left(E_{50}\right)$ at $0.3 \mu \mathrm{mol} / \mathrm{cm}^{2}(\sim 25.5 \mu \mathrm{g} /$ ear $)$ in croton oil-induced mice [12]. This inhibitory dose was 7.4 times lower than the $\mathrm{EC}_{50}$ reported in TPA-induced mice treated with hispidulin isolated from a medicinal plant $(223 \mu \mathrm{g} /$ ear $)$ [9]. It is, therefore, suggested that the effective doses from experiments using standard or purified compounds are more accurate and reliable than the effective doses from experiments using isolated compounds due to the absence of interference from other constituents in plant extracts.

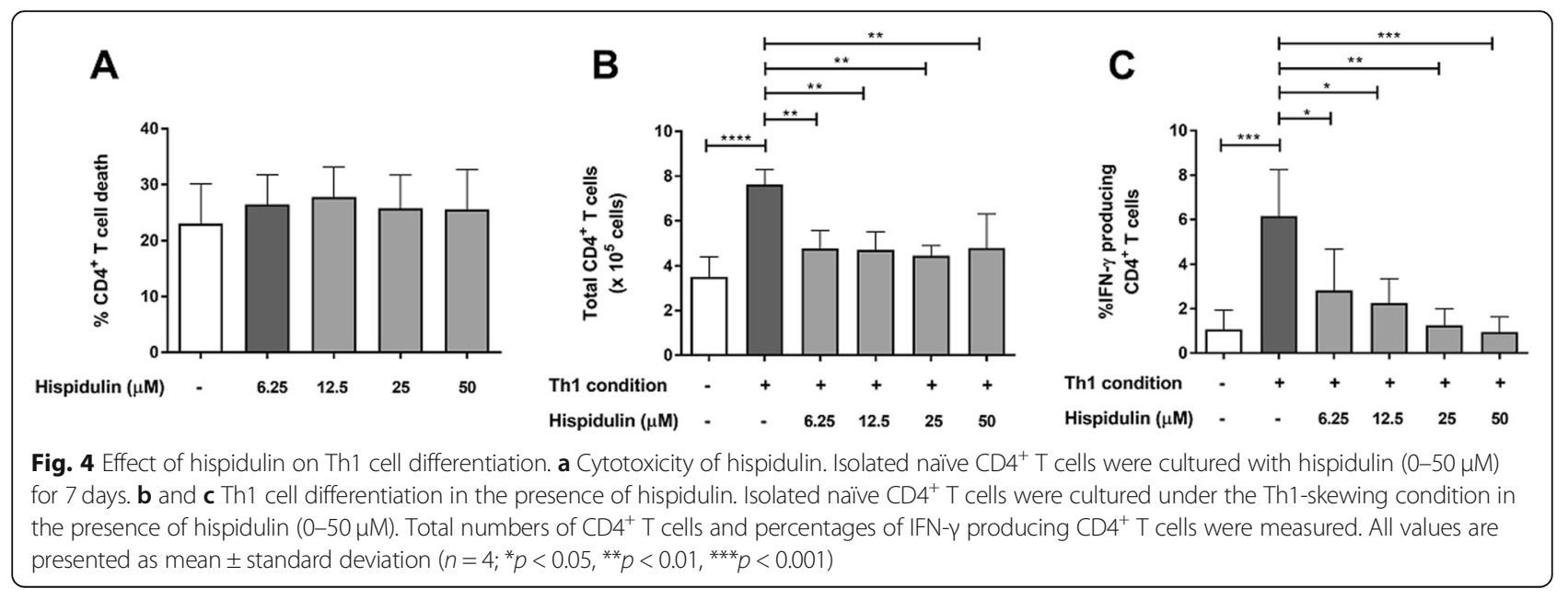


Hispidulin was also reported to have good penetrative activity for topical delivery due to its structure and physicochemical properties, with percutaneous absorption within $3 \mathrm{~h}$ [7, 17]. Our results showed that hispidulin $10 \mu \mathrm{g} /$ ear significantly suppressed ear swelling at 6-h post-challenge, and then its suppressive effect was reduced to almost the same level as the stimulated control at 24- and 48-h post-challenge. This may be due to the low concentration of hispidulin, which adversely affects its flux to the inflammation site over time. When the concentration was increased to $30 \mu \mathrm{g} / \mathrm{ear}$, the amount of hispidulin as a reservoir was presumably sufficient to maintain the flux longer and to contribute to a greater amount of absorption, which resulted in better suppression that was comparable to dexamethasone at both 6and 24-h post-challenge before the depletion of hispidulin at 48-h post-challenge. In overall comparison, dexamethasone was found to be more potent than hispidulin based on its continued efficacy at 48 -h post-challenge, and the fact that it performed better relative to the prevention of enlargement of ear thickness, edema, and spongiosis in vivo.

Since Th1 lymphocytes play a pivotal role in ACD pathogenesis, the mRNA expression level of IFN- $\gamma$ (which is upregulated in chronic ACD) in excised CHS murine pinna was measured to ensure the inhibitory effect of hispidulin at $30 \mu \mathrm{g} / \mathrm{ear}$. Hispidulin was found to possess suppressive properties equivalent to those of dexamethasone by downregulating IFN- $\gamma$ gene expression to the same level. Additionally, treatment with hispidulin at concentrations ranging from $6.25-50 \mu \mathrm{M}$ significantly decreased the total numbers of $\mathrm{CD}^{+} \mathrm{T}$ cells, and a similar degree of inhibition was found among the different concentrations. However, dosedependent suppression was observed for intracellular IFN- $\gamma$ production, and hispidulin at a low dose of $6.25 \mu \mathrm{M}$ was able to achieve only $50 \%$ inhibition. Hispidulin at all concentrations up to $50 \mu \mathrm{M}$ was confirmed as safe by not inducing $\mathrm{CD}^{+}{ }^{+} \mathrm{T}$ cell death. Taken together, these findings permit us to conclude that hispidulin regulated CHS reaction via suppression of Th1 cell function in IFN- $\gamma$ production, and not via reduction in Th1 cell frequencies. Our findings are in contrast to those of another study that reported that hispidulin at concentrations of $1-10 \mu \mathrm{M}$ significantly inhibited $\mathrm{T}$ cell proliferation in a dose-dependent manner [13]. However, that report did not identify which $\mathrm{T}$ cell subsets were suppressed by hispidulin, nor was any investigation of intracellular cytokine production described.

\section{Conclusions}

This study demonstrates the immunosuppressive property of hispidulin in ACD via reduction of infiltrated immune cells at the inflammation site, downregulation of
IFN- $\gamma$ gene expression, and suppression of Th1 skewing reaction (i.e., IFN- $\gamma$ production of $\mathrm{CD}^{+} \mathrm{T}$ cells), all of which result in decreased edema, spongiosis and ear swelling. Hispidulin also exhibits its inhibitory effect in a dose-dependent manner without inducing cell death and causing skin irritation. The results of this study suggest hispidulin as a novel immunosuppressant drug candidate for treatment of allergic contact dermatitis.

\section{Supplementary information}

Supplementary information accompanies this paper at https://doi.org/10. 1186/s12906-019-2689-z.

Additional file 1. Measurement of dermis thickness. Dermis thickness, excluding cartilage and epidermis, was measured by using

photomicrographs of ears at 48-h post-challenge. All values are presented as mean \pm standard deviation $\left(n=5 ;{ }^{*} p<0.05,{ }^{* *} p<0.001\right)$.

\section{Abbreviations}

ACD: Allergic contact dermatitis; ANOVA: Analysis of variance; APC: Antigen presenting cells; BFA: Brefeldin A; CD: Cluster of differentiation;

CDNA: Complementary deoxyribonucleic acid; CHS: Contact hypersensitivity; COX: Cyclooxygenase; Dex: Dexamethasone; DNCB: 2,4-dinitrochlorobenzene; DNFB: 1-fluoro-2,4-dinitrobenzene; FBS: Fetal bovine serum; FITC: Fluorescein isothiocyanate; H\&E: Hematoxylin and Eosin; His: Hispidulin; HO: Heme oxygenase; ICS: Intracellular cytokine staining; IFN-ү: Interferon-gamma; IL: Interleukin; iNOS: Inducible nitric oxide synthase; JNK: c-Jun N-terminal kinase; LPS: Lipopolysaccharide; mL: Milliliter; NF-kB: Nuclear factor kappa-lightchain-enhancer of activated B cells; ng: Nanogram; NO: Nitric oxide; Nrf2: Nuclear factor erythroid 2-related factor 2; OX: Oxazone; PBS: Phosphate buffered saline; PCR: Polymerase chain reaction; PE: Phycoerythrin;

PGE2: Prostaglandin E2; PI: Propidium iodide; PMA: phorbal 12-myristate 13acetate; RNA: Ribonucleic acid; RPMI: Roswell Park Memorial Institute; Th: T helper; TNCB: 2,4,6-trinitrochlorobenzene; TPA: 12-O-tetradecanoylphorbol-

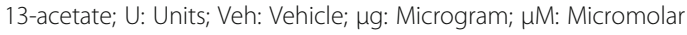

\section{Acknowledgements}

The authors gratefully thank Miss Supatra Mongkolwong for animal daily care.

\section{Authors' contributions}

PT: designed and conducted experiments, data analysis and manuscript writing; PP: performed experiments and data analysis; ST: performed experiments and data analysis; KS: designed and conducted experiments, data analysis, and manuscript editing. All authors read and approved the final manuscript.

\section{Authors' information}

Not applicable.

\section{Funding}

This study was financially supported by the Siriraj Foundation [D-003658] for data collection and was supported by the Faculty of Medicine Siriraj Hospital, Mahidol University for study design, data analysis, data interpretation and manuscript writing.

\section{Availability of data and materials}

All data generated or analyzed during this study are freely to any scientists wishing to use them for non-commercial purposes upon requested.

\section{Ethics approval and consent to participate}

All procedures performed in studies involving animals were in accordance with the ethical standards of Mahidol University and the Office of the National Research Council of Thailand (NRCT). All experimental protocols were approved by the Siriraj Animal Care and Use Committee (Si-ACUC), Faculty of Medicine Siriraj Hospital, Mahidol University, Bangkok, Thailand (COA no. 015/2559). 


\section{Consent for publication}

Not applicable.

\section{Competing interests}

All authors declare no personal or professional conflicts of interest, and no financial support from the companies that produce and/or distribute the drugs, devices, or materials described in this report.

\section{Author details}

'Siriraj Research Group in Immunobiology and Therapeutic Sciences, Faculty of Medicine Siriraj Hospital, Mahidol University, Bangkok, Thailand.

2Department of Pharmacology, Faculty of Medicine Siriraj Hospital, Mahidol University, 2 Wanglang Road, Bangkoknoi, Bangkok 10700, Thailand.

Received: 8 August 2018 Accepted: 20 September 2019

Published online: 15 October 2019

\section{References}

1. Kim H, Kim M, Kim H, Lee GS, An WG, Cho SI. Anti-inflammatory activities of Dictamnus dasycarpus Turcz., root bark on allergic contact dermatitis induced by dinitrofluorobenzene in mice. J Ethnopharmacol. 2013;149(2): 471-7.

2. Choi JK, Oh HM, Lee S, Park JW, Khang D, Lee SW, et al. Oleanolic acid acetate inhibits atopic dermatitis and allergic contact dermatitis in a murine model. Toxicol Appl Pharmacol. 2013;269(1):72-80.

3. Zemelka-Wiacek M, Majewska-Szczepanik M, Pyrczak W, Szczepanik M. Complementary methods for contact hypersensitivity (CHS) evaluation in mice. J Immunol Methods. 2013;387(1-2):270-5.

4. Bond WS. Toxic reactions and side effects of glucocorticoids in man. Am J Hosp Pharm. 1977;34(5):479-85.

5. Sitzia J, Huggins L. Side effects of cyclophosphamide, methotrexate, and 5-fluorouracil (CMF) chemotherapy for breast cancer. Cancer Pract. 1998;6(1):13-21

6. Quemeneur L, Michallet MC, Ferraro-Peyret C, Saint-Mezard P, Benetiere J, Ducluzeau MT, et al. Immunosuppressive antimetabolites inhibit induction of contact hypersensitivity while lymphoablative drugs also prevent its expression. Eur J Dermatol. 2003;13(6):540-7.

7. Thitilertdecha P, Guy RH, Rowan MG. Characterisation of polyphenolic compounds in Clerodendrum petasites S. Moore and their potential for topical delivery through the skin. J Ethnopharmacol. 2014;154(2):400-7.

8. Srisook K, Srisook E, Nachaiyo W, Chan-In M, Thongbai J, Wongyoo K, et al. Bioassay-guided isolation and mechanistic action of antiinflammatory agents from Clerodendrum inerme leaves. J Ethnopharmacol. 2015;165:94-102.

9. Gil B, Sanz MJ, Terencio MC, Ferrandiz ML, Bustos G, Paya M, et al. Effects of flavonoids on Naja naja and human recombinant synovial phospholipases $A_{2}$ and inflammatory responses in mice. Life Sci. 1994;54(20):PL333-8.

10. Akram M, Syed AS, Kim KA, Lee JS, Chang SY, Kim CY, et al. Heme oxygenase 1-mediated novel anti-inflammatory activities of Salvia plebeia and its active components. J Ethnopharmacol. 2015;174:322-30.

11. Clavin M, Gorzalczany S, Macho A, Munoz E, Ferraro G, Acevedo C, et al. Anti-inflammatory activity of flavonoids from Eupatorium arnottianum. J Ethnopharmacol. 2007;112(3):585-9.

12. Cottiglia F, Casu L, Bonsignore L, Casu M, Floris C, Sosa S, et al. Topical antiinflammatory activity of flavonoids and a new xanthone from Santolina insularis. Z Naturforsch C. 2005;60(1-2):63-6.

13. Yin Y, Gong FY, Wu XX, Sun Y, Li YH, Chen T, et al. Anti-inflammatory and immunosuppressive effect of flavones isolated from Artemisia vestita. $J$ Ethnopharmacol. 2008;120(1):1-6.

14. Chaiprasongsuk A, Lohakul J, Soontrapa K, Sampattavanich S, Akarasereenont P, Panich U. Activation of Nrf2 reduces UVA-mediated MMP-1 Upregulation via MAPK/AP-1 signaling cascades: the Photoprotective effects of Sulforaphane and Hispidulin. J Pharmacol Exp Thers. 2017;360(3):388-98.

15. Kim DE, Min KJ, Kim MJ, Kim SH, Kwon TK. Hispidulin Inhibits Mast CellMediated Allergic Inflammation through Down-Regulation of Histamine Release and Inflammatory Cytokines. Molecules. 2019;24(11):E2131.

16. Nagamachi M, Sakata D, Kabashima K, Furuyashiki T, Murata T, Segi-Nishida

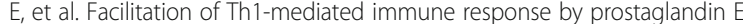
receptor EP1. J Exp Med. 2007;204(12):2865-74.
17. Thitilertdecha P, Rowan MG, Guy RH. Topical formulation and dermal delivery of active phenolic compounds in the Thai medicinal plant Clerodendrum petasites S. Moore Int J Pharm. 2015;478(1):39-45.

\section{Publisher's Note}

Springer Nature remains neutral with regard to jurisdictional claims in published maps and institutional affiliations.
Ready to submit your research? Choose BMC and benefit from:

- fast, convenient online submission

- thorough peer review by experienced researchers in your field

- rapid publication on acceptance

- support for research data, including large and complex data types

- gold Open Access which fosters wider collaboration and increased citations

- maximum visibility for your research: over $100 \mathrm{M}$ website views per year

At $\mathrm{BMC}$, research is always in progress.

Learn more biomedcentral.com/submissions 